\title{
5] 可逆転ポンプを用いる拍動流型完全人工心臓の検討
}

福永信太郎, 三井法真, 末田泰二郎, 松浦雄一郎 (広島大第一外科)

〔目的〕体内植え込反型人工心臓として使用する目 的で，1台のロータリーポンプを用いて左心系と右心 系を拍動流で左右交互拍出する血液ポンプについて検 討した.

[方法】这転可能なポンプの流入側拉よび流出側に 人工弁をそれぞれ 2 個ずつ取り付け，これを血夜ポン プとする．流入側には人工弁を 2 個並列に互いに逆向 きに取り付け，僧帽弁と肺動脈弁とし，流出側にも同 様に取り付け，大動脈弁と三尖弁とする.

ポンプを順方向に回転すると，血液が僧帽弁から流 入してポンプで加圧され, 大動脈弁から吐出される. このときポンプは左室として機能し，肺動脈弁と三尖 弁はそれぞれ肺動脈圧および左室圧で閉鎖している. ポンプを逆転するとポンプ内部の流れの方向が反対に なり，血液は三尖弁から流入して肺動脈弁から吐 し, ポンプは右室として機能し, 大動脈弁と僧帽弁は それぞれ大動脈圧と右室圧によって閉鎖している。
直流モータ駆動小型ギヤポンプを用い, 僧帽弁と三 尖弁をりザーバー $(10 \mathrm{mmHg})$ 飞, 大動脈弁之肺動 脈弁をへッドタンク（それぞれ $80 \mathrm{mmHg}, 20 \mathrm{mmHg}$ ) 飞接続し, 生理食塩水を用いて流量を大動脈弁の位置 で測定した.

[結果]用いたギヤポンプが最大 $1.7 \mathrm{~L} / \mathrm{min}$ と小 さかったので, 観察された流量は拍動数が $60 \mathrm{bpm} の$ 時に $0.8 \mathrm{~L} / \mathrm{min}, 85 \mathrm{bpm}$ で $0.8 \mathrm{~L} / \mathrm{min}, 110 \mathrm{bpm}$ で $0.75 \mathrm{~L} / \mathrm{min}$ であった.

[考案] 1 台の可逆転ポンプと 4 個の人工弁を用い た血液ポンプで, 拍動流で両心室の循環機能を代行で きる可能性が示唆された。ポンプの回転方向切り替兄 時にポンプ内に残留する血液によって静脈血が動脈血 に混合すること，人工弁閉鎖時に右室から左房へ，肺 動脈から左室（扰張期に相当）への逆流が生じること など，解決すべさ問題点む残されている。

\section{6 心筋冷却用アイススラッシュ製造装置 ( 2 号機)の臨床評価に関する研究}

酒井順哉, 吉中平次, 大山 勝（鹿児島大病院中央手術部） 鈴木瑞穂, 加藤直史 (豊田メディカル)

心筋冷却を必要とする開心術に扎いて，乳酸りンゲ ル液から作られる無菌アイススラッシュが手術中何時 でも供給できるようにすることは重要なことである.

今日でも多くの病院で性, フイススラッシュ製造の ために, 滅菌 2 重ビニールパックに充填された乳酸り ンゲル液を長時間冷凍庫で涷結後, 必要な数量のパッ クを手術中に金棺で碎き, 滅菌を施した氷削器でスラ ッシュ状態にするといら手術手技に比して非近代的な 製造方法が用いられている。この方法は，金棺での砕 き方熟練が必要であり，ともするとビニールパック の切片がアイススラッシュに混入したり, 不潔操作の 危険性もあるなどの問題も多かった.

別法として, 冷凍庫で 4 時間程冷凍してアイススラ ッシュを作る方法もあるが，手術に使用する予定時刻 から逆算して, 当直看護婦が深夜に冷凍庫に乳酸りン ゲルパックをセットする必要があるとともに，時間経 過後に過冷却に上る凍結を防止するため冷凍庫から取 り出す作業時刻を徹底することが不可欠であった。
いずれの方法も，アイススラッシュ製造のために専 用の機械を必要としない長所はあるが，看護婦の業務 省力化と安定した均一なアイススラッシニの常時供給 には多くの問題点があった。

主な改善点として, (1)アイススラッシュ状態をさら に安定させる, (2)アイススラッシュ保存時間を長くす る工夫を施す，(3)ストパフォーマンスのよい部品を 選択し，製造価格を安くするなどである。

我々は，手術中，その準備作業を行う外回り看護婦 の省力化を図り，安定した均一のアイススラッシュを 常時供給できるようにするには，専用のアイススラッ シュ製造装置の開発が必要と考方，1993年 9 月にその 1 号機を試作した.

1 号機は, 試作と同時に鹿児島大学手術部で心筋冷 却を必要とする全ての開心術時に利用し，その有効性 と今後の改良点を見いだすことがでさた，今回，アイ ススラッシュ製造装置の製品化を前提として，2号機 の開発を行ったので，ここにその概要を報告する. 